\title{
O CHEIRO DOENTIO DO CONTATO: DOENÇA, HISTÓRIA E DEGRADAÇÃO AMBIENTAL ENTRE OS KARITIANA NA AMAZÔNIA OCIDENTAL ${ }^{1}$
}

\author{
Felipe Ferreira Vander Velden ${ }^{2}$
}

\begin{abstract}
Resumo
Partindo de uma interpretação singular que os Karitiana, grupo Tupi-Arikem em Rondônia, propuseram para um evento que acompanharam pela televisão, este artigo pretende refletir sobre as relações entre a doença, a história e o meio-ambiente no contexto das relações interétnicas e dos graves e complexos problemas criados pelo contato para as sociedades indígenas nas terras baixas sul-americanas. 0 texto sugere que os Karitiana estão atentos aos diversos acontecimentos ao redor do planeta, e refletem sobre eles a partir de seus parâmetros cosmológicos. Assim, produzem comentários de alcance global que podem ser tomados como formas de conhecimento e crítica ambientais, ao abranger, por exemplo, as relações com a história, com 0 cosmos e com seus habitantes, humanos e não-humanos.
\end{abstract}

Palavras-chave: Doença. Meio-ambiente. Karitiana. Ecologia.

\footnotetext{
${ }^{1}$ Esta é uma versão bastante modificada do trabalho apresentado na $25^{\text {a }}$ Reunião Brasileira de Antropologia, ocorrida entre 11 e 15 de junho de 2006, em Goiânia. Agradeço os comentários e sugestões de Ricardo Ventura Santos, Flávio Wiik, Maurício Soares Leite e Sílvia Aguiar Carneiro Martins, à leitura atenta e crítica de André Borges de Mattos e Clarissa Martins Lima, e ao auxílio dos amigos Guilherme Mansur Dias e André Martini. Agradeço também à Marina Cardoso pelo convite para publicação do artigo neste volume.

${ }^{2}$ Professor do Departamento de Ciências Sociais e do Programa de Pós-Graduação em Antropologia Social da Universidade Federal de São Carlos, Brasil. felipevelden@yahoo.com.br
} 


\title{
THE SICKENING SMELL OF CONTACT: DISEASE, HISTORY AND ENVIRONMENTAL DEGRADATION AMONG THE KaRITIANA IN Western Amazonia
}

\begin{abstract}
Starting from a singular interpretation that the Karitiana, a Tupi-Arikem group in Rondônia, proposed for an event they have watched on television, this article intends to reflect on the relations between disease, history and the environment in a context of inter-ethnic relations and serious and complex problems this contact created in indigenous societies in South-America lowlands. The text suggests that the Karitiana are aware of the various events around the globe, and that they reflect on them based on their cosmological parameters. Thus, they produce comments of global reach that can be taken as forms of knowledge and environmental criticism including, for example, the relations with history, cosmos and its inhabitants, both humans and non-humans.
\end{abstract}

Keywords: Disease. Environment. Karitiana. Ecology.

Como se os primeiros irmãos fossem gigantes, heróis, gloriosos, homens enormes, e desde este tempo, os homens de Deus, como os homens sem Deus, aliás, e como toda coisa neste mundo cá de baixo, não deixaram nunca mais de atarracar, de encarquilhar, de geração em geração, desde o tempo dos gigantes, e se isso continuasse, não sobraria mais nadinha, ou então anões, ou então o pó cinzento e as noites.

Gilles Lapouge, A Missão das Fronteiras.

\section{INTRODUÇÃ̃O}

0

s Karitiana, povo de língua Tupi-Arikém cuja terra indígena se localiza no norte do Estado de Rondônia (VELDEN, 2010a)3 , são consumidores regulares da programação visual oferecida pelas redes de TV aberta do

\footnotetext{
${ }^{3}$ Apopulação Karitiana está, atualmente, em torno de 350 indivíduos, de acordo com recenseamento efetuado por Íris Araújo em 2011. Aproximadamente 200 índios habitam a aldeia Kyõwã, na Terra Indígena Karitiana, onde a maior parte da minha pesquisa de campo foi realizada e onde os fatos narrados aqui se desenrolaram. Há outras três aldeias Karitiana construídas recentemente, depois de 2005. São elas: Byyjyty ot'soop aky, na margem direita do rio Candeias; Jojbit o'mirim, no igarapé Preto; e Bom Samaritano, bem próxima de Kyõwã (as duas primeiras fora da área hoje demarcada). Os Karitiana restantes vivem em cidades próximas. Meu trabalho de campo totalizou 13 meses, entre 2003 e 2011.
} 
Brasil. Virtualmente, todas as residências possuem seus próprios aparelhos de TV (ainda que só algumas tenham as necessárias antenas parabólicas). A recente oferta contínua de eletricidade - para a aldeia Kyõwã depois de 2008; as outras três aldeias (Byyjyty Ot'soop aky, E'se emo e Bom Samaritano) ainda não dispõem de fornecimento de energia - leva muitas pessoas diariamente a se aglomerarem em torno dos televisores para acompanhar, sobretudo, novelas, telejornais e partidas de futebol. Quando se deslocam para Porto Velho e se hospedam na Casa do Índio (construção vizinha ao prédio do Núcleo de Apoio Local da FUNAI, que abriga os índios em trânsito pela cidade), os Karitiana frequentemente carregam junto com seus pertences vários televisores, que ali permanecem diuturnamente ligados.

Minha intenção aqui, contudo, e ao contrário do que pode parecer, não é discutir em detalhes o modo singular como os Karitiana apreendem a televisão ou seu conteúdo de forma geral: este pequeno preâmbulo pretende somente apontar este veículo como uma modalidade crescente de circulação de informações nas comunidades indígenas no Brasil atual e sugerir que as interações entre os povos indígenas e mídias contemporâneas diversas vêm produzindo interpenetrações discursivas interessantíssimas, mas que ainda aguardam análise acurada. Isso indica que grupos como os Karitiana não dependem mais, apenas, da interface entre práticas e agentes "tradicionais" e "modernos" in situ para a formação de seu conhecimento atual e atualizado sobre saúde, doença, história, meioambiente, contato, entre outras coisas; pois há outras fontes de saber que cada vez mais introduzem novos dados e estimulam a construção de perspectivas diferentes dos problemas - algumas até, como veremos, de alcance internacional ou global.

Os possíveis impactos disso na relação cotidiana entre agentes do conhecimento científico-acadêmico e as populações indígenas está para ser avaliado. Neste artigo, pretendo explorar uma faceta deste processo: como uma informação particular chegou até os Karitiana, e a maneira pela qual esta informação foi recebida e lida a partir da teoria indígena da doença, dos efeitos do contato e da ação dos brancos sobre o quadro etiológico e ambiental local e global e sobre a qualidade de vida dos índios em particular e da humanidade em geral. Além disso, pretendo explorar algumas consequências teóricas e pragmáticas sugeridas pelas interpretações, feitas pelos Karitiana, de certa informação veiculada pela televisão.

A informação: pouco antes de minha primeira entrada na Terra Indígena Karitiana, no dia 20 de maio de 2003, forças militares norte-americanas e 
britânicas (em sua maioria) invadiram o Iraque de Saddam Hussein. Os exércitos dos Estados Unidos e da Inglaterra foram recebidos por uma aguerrida resistência das milícias iraquianas, e a guerra ali iniciada terminou formalmente apenas em dezembro de 2011, com a retirada total dos últimos soldados estadunidenses e a entrega formal do comando das tropas ao novo governo iraquiano. Os telejornais brasileiros e de todo o mundo noticiaram com destaque a intervenção angloamericana naquele país do Médio Oriente, especialmente no que concerne - 0 que é de praxe - aos campos de exploração de petróleo (do que o Iraque é, ou era, um grande produtor e fornecedor), à tecnologia militar sofisticada dos exércitos ocidentais e às centenas de baixas diárias, tanto entre civis iraquianos quanto entre os soldados estrangeiros invasores 4 . Uma "boa guerra", em que imagens de incêndios, explosões e sangue, evidentemente, não falta(ra)m5. Foram estas imagens que causaram impacto certeiro aos olhos dos Karitiana.

Os comentários dos índios giravam em torno da fumaça produzida pelas bombas, explosões e pelos campos de petróleo em chamas que a TV exibia (e ainda exibe) diariamente; e em torno de um composto particular desta fumaça: 0 cheiro do sangue (ge opira) coalhado que se espalhava e se misturava à fumaça negra dos artefatos bélicos e oleodutos incandescentes, e subia ao céu, segundo os Karitiana, carregado pelos ventos. Na mesma ocasião em que os índios assistiam a estas imagens, uma epidemia de conjuntivite atingiu a aldeia Kyõwã por alguns dias, e foi atribuída à fumaça produzida no Iraque, que teria subido, circulado pelo planeta por meio dos ventos "contaminando tudo", e chegado, ainda que enfraquecida, à Amazônia. Julgavam os índios, não sem alguma especulação, e fortemente amparados pelos conhecimentos médicos adquiridos pelos funcionários do posto de saúde local, que a mera presença de uma pessoa doente

\footnotetext{
${ }^{4}$ Segundo a ONG Irak Body Count (IBC) se estima que mais de 160 mil pessoas perderam a vida no conflito desde 2003 até o início de 2012. As estimativas, contudo, são bastante díspares (IRAQUE..., 2012).

${ }^{5}$ Imagens como estas, de morte e destruição, puderam ser vistas, apesar de as guerras norteamericanas no Iraque (desde a Guerra do Golfo, em 1990-1991) terem sido consideradas, acima de tudo, enormes espetáculos orquestrados pela mídia, que controlou todo o tempo a circulação de informações e de imagens, empregando-as de modo estratégico para conduzir os conflitos na direção que almejava (KELLNER, 1992). Ademais, a visão das luzes dos foguetes e a exibição de força tecnológica foram um tétrico espetáculo, cujas dimensões midiáticas se interpenetraram de formas muito problemáticas com a política norte-americana (BARBROOK, 2009).
} 
era responsável pela disseminação da moléstia ${ }^{6}$; mais, a infecção fora trazida por um Karitiana recém-chegado da cidade; e, além do mais, a fumaça dos carros eventualmente circulando pela aldeia, aliada à fumaça dos "motores" (gerador a óleo, motosserras, tratores, máquinas em geral) e dos muitos cigarros consumidos pelos homens, funcionavam como poderosos agravantes da infecção nos olhos.

Pude, então, agarrar uma das pontas do fio que me conduziria até uma interpretação das noções Karitiana da doença e de seu papel crucial na história das relações deste grupo indígena com os primeiros invasores brancos e com a população não indígena circunvizinha. Pude, ademais, perceber como esta visão da doença está articulada ao modo Karitiana de refletir sobre o espaço habitado convertendo-se, no limite, em uma modalidade de crítica ao desenvolvimentismo e à devastação ambiental. Este artigo procura refletir sobre esta espécie de bibrido - amálgama de teorias indígenas sobre a doença, o ambiente e, no limite, o mundo e de crítica à devastação ambiental - constituído na interface entre os conhecimentos e as experiências dos Karitiana e sua atenção a acontecimentos que se desenrolavam do outro lado do globo. Aqui não estarei lidando com uma categoria específica, ainda que as reflexões dos Karitiana sobre a Guerra do Iraque também articulem as noções de "pessoa, saúde, corpo e meio-ambiente dessa população" e "as práticas relacionadas a essas dimensões" (WAWZYNIAK, 2003, p. 35) de modo a oferecer um vislumbre de sua cosmologia em ação no mundo contemporâneo, mesmo que radicada em um ponto perdido da Amazônia brasileira.

\section{CONTATO E DOENÇA NA HiSTÓRIA KARITIANA}

Não se sabe com precisão as datas dos primeiros contatos dos Karitiana com os brancos: é possível que os grupos de língua Tupi-Arikém na região dos formadores da margem direita do alto rio Madeira tenham sido atingidos por frentes de exploração da borracha e do caucho no final do século XVIII e início do XIX (MEIRELES, 1984). Em 1907, a Comissão Rondon fez, ao que parece, a

\footnotetext{
${ }^{6}$ Digo "julgavam" porque o modo de transmissão da conjuntivite ainda estava em discussão pelos Karitiana naquela ocasião. Certa vez, eu, que também fui vítima da infecção, disse a um pequeno grupo de índios que estavam a certa distância de mim (portanto, sem contato físico direto), e ainda não infectados, que iria transmitir-lhes a doença, fazendo gestos que sugeriam que eu tirava alguma coisa dos olhos e jogava em sua direção; os índios protegeram os olhos com as mãos, ou deixaram o local, reclamando indignados.
} 
primeíra referência aos Karitiana na literatura, localizando-os no médio curso do rio Jaci-Paraná (RONDON, 1907, p. 329) e, logo em seguida, um ataque contra membros da Comissão confirmou a presença dos Karitiana ali (PINHEIR0, 1910). 0 contato intensivo, no entanto, só teve início a partir da década de 1950 - com a intervenção de funcionários do SPI e de missionários salesianos na região - e culminou com a instalação dos Karitiana no sítio da principal aldeia atual (no interior da Terra Indígena) no princípio dos anos de 19707.

0 histórico das relações entre os Karitiana e os brancos é, como para numerosos grupos indígenas nas terras baixas sul-americanas, uma história de perdas, de destruição e de sofrimento (ALBERT, 2002). Por esta razão, o período anterior ao contato é visto pelo grupo como tempo de fartura, de abundância e de saúde plena; mais do que isso, é lembrado como uma época em que os corpos não eram marcados pela doença e pelo sofrimento, não haviam sido atingidos, ainda, pelo selo da degradação física; memória inscrita no corpo (G0W, 1991; 1997) pelos efeitos deletérios do contato, os Karitiana se veem hoje pequeninos, mirrados, fracos, e se espantam com a exuberância física dos guerreiros Uru-euuau-uau, seus vizinhos ao sul e tradicionais inimigos, que por vezes encontram em Porto Velho. Estes são, hoje (como também os Cinta Larga, esses mais distantes), a imagem do que aqueles eram, tempos atrás, altos, fortes, agressivos, poderosos.

Tais tempos de fartura e saúde foram sucedidos pelo surgimento das doenças bravas trazidas pelos brancos, cujo resultado foi uma dramática redução populacional dos Karitiana, que chegaram a ser apenas 45 indivíduos em 1967 (KIETZMAN, 1967). As agruras que se seguiram aos primeiros contatos são sintetizadas neste depoimento que o finado Garcia Karitiana (falecido em 2010) deu a Lilian Moser (1993, p. 142-151), no qual fala da quantidade de doenças que assolaram os Karitiana nos primeiros contatos, como seu número foi drasticamente reduzido na ocasião, e como estes fatos afetam a vida do grupo ainda nos dias de hoje:

[...] tempo antigamente pega muita gripe, catarro, pneumonia, né [sic]. Na hora que a gente tem braba. Matava muita gente, certo. Primeiro que a gente fazia contato com o branco. Por isso até hoje sentindo doente [...].

\footnotetext{
${ }^{7}$ Para uma revisão da história do contato dos Karitiana ver Meireles, 1984; Hugo, 1991; Moser, 1993; Velden, 2004, 2010a.
} 
A trajetória histórica do contato e do convívio com os não índios também reflete sobre as drásticas alterações produzidas pela colonização no território Karitiana. Com efeito, os índios são unânimes em afirmar que os recursos naturais estão muito degradados, e que o meio ambiente em que vivem está bastante empobrecido em comparação com tempos passados. Todos concordam, ainda, que a caça diminuiu consideravelmente, que a pesca está mais e mais prejudicada pela poluição dos rios e igarapés e pelo barramento (pelos fazendeiros vizinhos da Terra Indígena) dos principais cursos d'água que abastecem Kyõwã, provocando, especialmente, a ausência das jatuaranas - pojpok, um peixe muito apreciado e importante na realização de um ritual, a festa da jatuarana, pois considerado um peixe "limpo", motivo pelo qual o ritual há anos não acontece. Também consideram que as terras agricultáveis vêm encolhendo em extensão, ao mesmo tempo em que solos férteis têm de ser buscados cada vez mais longe da aldeia. Em 2011, visitas efetuadas a seu território tradicional, na margem direita do rio Candeias (desocupada pelo grupo quando de sua migração forçada para o oeste, em meados do século passado), apenas confirmaram a destruição da maior parte da floresta e sua substituição por pastagens. Mais recentemente a construção de duas grandes usinas hidrelétricas no rio Madeira (Santo Antônio e Jirau), bem próximas da Terra Indígena Karitiana (ALMEIDA, 2009), adicionam, com todos os seus possíveis impactos, uma nota adicional a esta triste história das alterações ambientais provocadas pelo estilo de vida predatório dos brancos.

Instrumento retórico indígena que serve a uma política de depreciação das condições de vida, produção e saúde atuais e a busca intensa por melhorias via edenização do tempo pretérito e uma busca por regressar, de certa forma, no tempo (VELDEN, 2010b) -, este passado vigoroso está além das possibilidades de qualquer investigação, tanto mais porque são absolutamente exíguos os registros históricos escritos sobre os Karitiana. Se, portanto, sobre este aspecto não temos como conhecer os Karitiana antes do contato, podemos, todavia, explorar os modos como os Karitiana concebem sua trajetória histórica de relacionamento com a doença e a degradação ambiental, e as maneiras pelas quais este discurso se articula tanto ao conhecimento médico adquirido com os serviços de saúde oferecidos pelos brancos, quanto aos saberes ambientais, nativos ou aprendidos após o contato, bem como a outras reflexões suscitadas pelo contato e pelo relacionamento com a sociedade nacional envolvente ${ }^{8}$.

${ }^{8} 0$ que pretendo oferecer aqui é apenas um resumo muito sucinto da teoria etiológica Karitiana.

O CHEIRO DOENTIO DO CONTATO: DOENÇA, HISTÓRIA E DEGRADAÇÃO... 
Entre os Karitiana a doença (kida oti) é uma ameaça sempre presente: ela está "no ar", o tempo todo em torno da aldeia, assim como em volta dos indivíduos, sempre disposta a transpor as barreiras e penetrar no terreno ocupado pelas residências e, após isso, nos corpos. Diz-se que a doença encosta no corpo, ou que ela "tem veneno", e que sua proximidade é responsável pelo adoecimento e morte9. Parece haver alguma inconsistência nas informações sobre a "intencionalidade" das doenças: se elas são, efetivamente, espíritos, ou se elas são provocadas por certos seres maléficos, e dotados de agência destrutiva, reconhecidos como espiritos (psam'em) ou como bichos - kida. Esta última é uma categoria genérica para certos seres monstruosos e maléficos que povoam o universo, que pode incluir desde criaturas sobrenaturais até animais e mesmo pessoas (DAMATTA; SOÁREZ, 1999, p. 12; WAWZYNIAK, 2003, p. 41), e que "jogam" as doenças sobre as pessoas ou executam certos atos que provocam moléstias nos humanos. É interessante que os Karitiana especulem em alguns momentos, a partir do que aprenderam na escola ou com agentes de saúde e de controle de endemias, que a malária seja transmitida pelo mosquito anofelino (chamado mãe da malária); não obstante, a doença continua sendo pensada como entidade invisível que circunscreve ameaçadoramente a aldeia e os indivíduos. Estes espíritos ou bichos maléficos estão associados a diferentes fenômenos atmosféricos (certas qualidades de chuva, trovões e relâmpagos, assim como ventos e redemoinhos) cuja manifestação indica a ameaça (sempre) presente de doença. Estaríamos, talvez, diante do tipo de agência descrito por Castro (1986) como "efeito-espírito"?

De fato, parece haver uma simetria, no processo de adoecimento, entre a perspectiva do indivíduo e aquela do grupo; e isso pode ser observado nas várias ações rituais, que podemos dizer profiláticas, tanto individuais como coletivas, que os Karitiana executam para manter as doenças afastadas. Várias folhas e cascas de árvores, glosadas geralmente como remédios (cujo termo genérico em Karitiana é gopatoma), são utilizadas em infusões para banhos ou simplesmente esfregadas no corpo, ou ainda mantidas em certos locais das casas: diz-se que, com isto, elas impedem que as doenças se aproximem e "colem", "grudem" nas pessoas. Interessante notar que estas plantas comunicam aos corpos características suas, às quais se credita a eficácia contra a aproximação das doenças: assim,

Mais informações podem ser encontradas em Velden (2004, 2007).

${ }^{9}$ A questão da agência (ou intencionalidade) dos poderes patogênicos ou agressivos é discutida em detalhes por Sztutman (2005, p. 174-207). 
plantas de tronco espinhoso permitem afugentar as enfermidades, pois estas temem os espinhos e não se aproximam demasiadamente; plantas com tronco especialmente liso ajudam a tornar os corpos também escorregadios, fazendo com que as doenças não possam neles se agarrar; plantas amargas - e a maioria das folhas empregadas como remédios são consideradas muito amargas (tapo) - tornam os corpos amargos, repelindo as doenças, que apreciam corpos doces (VELDEN, 2008). Não é fortuito, pois, que os Karitiana também denominem estas plantas, na língua portuguesa, como "vacinas" ou "fortificantes", pois sua ação é antes preventiva do que curativa.

Se, individualmente, o uso destas plantas-remédio forma como que uma barreira protetora do corpo, os rituais coletivos se destinam a erigir um obstáculo que proteja toda a aldeia da penetração destrutiva das moléstias: a imagem deste cenário, desenhado para mim, certa vez, no chão de terra, assemelha-se ao desenho simples do sol, um círculo (a aldeia, ou em cujo interior está a aldeia) cercado de raios por todo lado (as doenças, mantidas afastadas, mas sempre por ali). Desconfio que o mecanismo coletivo de profilaxia seja análogo ao que é utilizado pelos indivíduos cotidianamente, posto que a festa do gopatoma - um importante ritual profilático Karitiana - é realizado sob os troncos cobertos de espinhos das palmeiras marajá (Bactris maior Juss., chamada pelos Karitiana de pente de macaco) (BORZACOV, 2004, p. 188), um aviso às doenças para que não se aproximem demasiadamente. Nestas festas, todos os participantes se banham com as plantas agrupadas sob o termo gopatoma, o que confere proteção ao grupo.

É razoável sugerir que, segundo a perspectiva Karitiana, a trajetória espacial seguida pelo contato emulou a forma "tradicional" de propagação das doenças. Compreende-se, pois, que a aldeia de antigamente seja pensada pelos Karitiana de hoje como um universo fechado, quiçá livre das doenças em função dos rituais profiláticos, como já visto: diz-se que, antigamente, os Karitiana não adoeciam com facilidade ${ }^{10}$. 0 que os brancos fizeram, dizem, foi abrir uma

\footnotetext{
${ }^{10}$ Os estudos sobre as trajetórias das doenças infecciosas trazidas para o continente americano após a conquista de certa forma corroboram esta percepção: o isolamento de muitos grupos distantes das frentes de contato ou evitando-as ativamente - permitiu que escapassem, durante mais ou menos tempo, das novas doenças (KUNITZ, 1994, p. 306-309). Apenas é importante, neste caso, o cuidado com a ilusão presentista, que vê os grupos indígenas sul-americanos sempre como mônadas isoladas e autônomas, uma vez que isto corresponde muito mais a um cenário contemporâneo do que à situação nos momentos de conquista; sabemos de vários casos em que densas redes de contato entre diferentes povos levaram artefatos e doenças para regiões muito
} 
passagem mortal entre seu estável universo aldeão e as cidades, percebidas como os locais por excelência da degradação, da violência e da propagação desenfreada das doenças. Isto é, um caminho, rasgado na floresta, que conectou a aldeia ao mundo dos brancos, permitindo a passagem do ar e da fumaça e, com ele, das doenças bravas (kinda oti sara ou kida oti sara sara), ou doenças de branco, desconhecidas antes do contato e particularmente agressivas e mortais (malária, diarreias, febres, tuberculose - "tosse brava"). Este trajeto entre os Karitiana e as povoações dos brancos se construiu por meio da derrubada brutal da floresta circundante, e a disposição geográfica do território Karitiana atual - a aldeia Kyõwã, conectada à rodovia federal BR-364 e à cidade de Porto Velho por uma única estrada, aberta por exploradores de cassiterita ainda nos anos de 1970 oferece uma imagem bastante convincente deste percurso histórico. 0 desenho abaixo ilustra o cenário:

Figura 1 - o percurso aberto pelos brancos até atingir a aldeia Kyõwã, abrindo uma brecha na cobertura florestal e permitindo a passagens de pessoas, fumaça e doenças

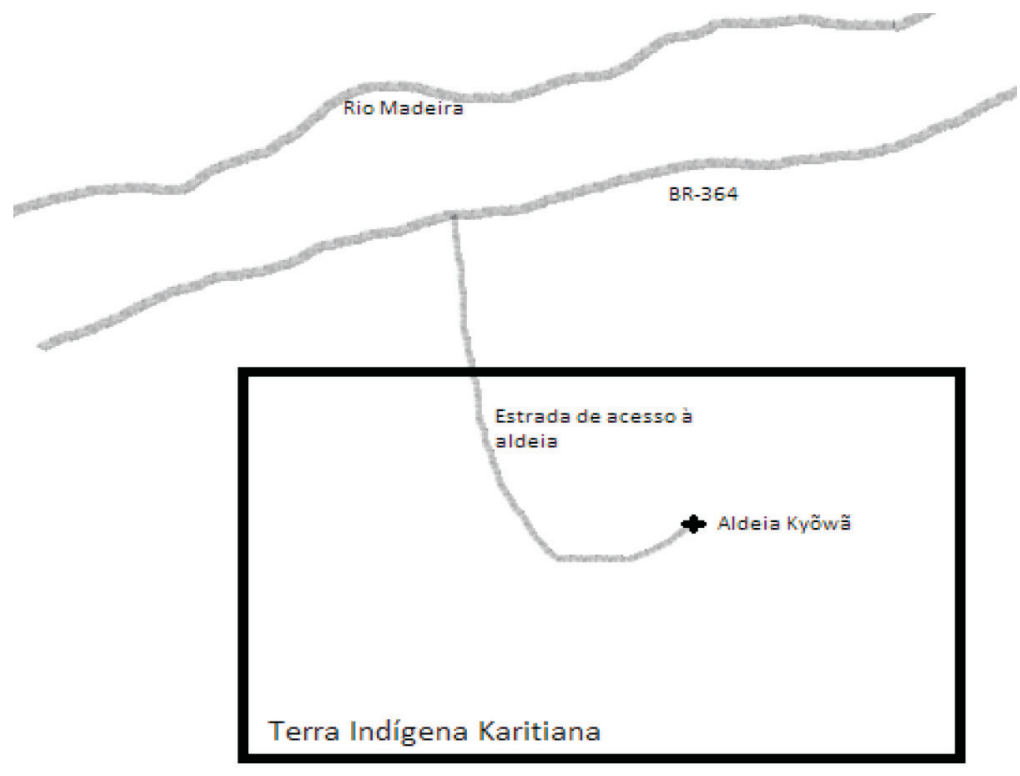

Fonte: Autor

distantes e que só seriam atingidas pelos colonizadores muito tempo depois (ALBERT, 1992; COOK, 1998; CROSBY, 1972; HEMMING, 1987). 
0 caminho aberto pelos brancos trouxe novas doenças diretamente do mundo urbano para a aldeia Kyõwã, através da trilha que a estrada cortou na mata. 0 os Karitiana especulam se isto não ocorreu justamente porque se abriu um canal que permitiu a difusão, por meio dos ventos, da enorme quantidade de fumaça produzida pelos não-índios com seus veículos motorizados, indústrias, maquinarias e mesmo cigarros, além, é claro, das gigantescas queimadas florestais para a abertura de pastos e a criação de fazendas que assolam o estado de Rondônia desde pelo menos os anos de 1970 (FEARNSIDE, 1989). A ideia de que 0 ar e/ou o vento transportam agentes patogênicos é difundida nas terras baixas da América do Sul. Wiik (2001, p. 399) registra que os Xokléng, no interior de Santa Catarina, também conectam a emergência de novas e graves doenças pós-contato (Zug-Kongó) aos ventos que as trazem das cidades dos brancos, e que penetram nos territórios indígenas através das áreas florestais devastadas pelos invasores. Os Awá-Guajá também associam a fumaça das queimadas promovidas na floresta por seus vizinhos com diversas doenças, que são carregadas pelos ventos. Não obstante, os ventos também podem ter consequências positivas, associadas à cura e à viagem dos espíritos dos mortos para o mundo celeste (CORMIER, 2003, p. 104, 106-108). A descrição dos assim chamados males de aires ("maus ventos") - que são ataques de espíritos - como expressão das relações históricas (e, no mais das vezes, desmedidas) entre indivíduos, grupos humanos e entre estes e a natureza são admiravelmente elucidadas por Taussig (1993, p. 329-331, 348-353). 0 assim chamado vento-mau é um importante agente etiológico entre os Kariri-Xocó, Alagoas (SILVA, 2004, p. 99). Esses exemplos me parecem ilustrar a importância do tema nas terras baixas, e poderiam ser multiplicados.

Ventos transportam, no caso Karitiana em tela, os cheiros da fumaça e do sangue e, neste sentido, pode-se perceber como os odores são agentes poderosos da percepção do universo, dos seres que o povoam e das modalidades de relação que eles entretêm, em especial com respeito à difusão das doenças (CROCKER, 1985; SEEGER, 1981) ${ }^{11}$. Sem a intenção de oferecer uma classificação dos cheiros entre

\footnotetext{
${ }^{11}$ Além destas duas etnografias clássicas, as complexas relações entre odores e os estados de saúde e doença vêm sendo exploradas por muitas etnografias recentes nas terras baixas sul-americanas. Ver, entre incontáveis exemplos, Novaes (1996, p. 217), sobre a preferência dos Wari' pelos remédios de cheiro forte; Farage (1997), para uma discussão detalhada a respeito dos odores de plantas entre os Wapishana e a relação dos cheiros perfumados/pútridos com os estados da pessoa; Keifenheim (2002), sobre o olfato como órgão fundamental para a percepção da realidade entre os Kaxinawá e da indicação de perigo relacionada à associação entre odores singulares e espíritos
} 
estes índios, deve-se dar destaque, no caso dos Karitiana, aos odores dos animais, ao odor do sangue e ao da fumaça.

A percepção, classificação e as implicações simbólicas do cheiro dos animais é um tema comum na etnologia sul-americana, registrado e discutido em vários estudos clássicos (CASTR0, 1977, 2002; CROCKER, 1985; SEEGER, 1981). Sua associação com a doença, no caso Karitiana, nos remete ao cheiro forte atribuído a algumas espécies (opira ou hydna; os Karitiana empregam, traduzindo estes conceitos, o termo regional, pitiú) que, consideradas fedidas ou cuja carne é tida como malcheirosa, não devem ser tocadas ou consumidas, pois estão associadas a certas feridas no corpo e doenças de pele.

Os perigos associados ao cheiro do sangue também remetem a várias etnografias (FARAGE, 1997; FAUSTO, 2001; MONTAGNER, 1996; VERANI, 1991), e se articulam aos problemas colocados pelos estados críticos da pessoa, em que há derramamento desta substância vital: parto, rituais de escarificação, ferimentos acidentais, morte e homicídio. Algumas cosmologias afirmam que os odores das pessoas podem penetrar as outras, ocasionando doenças (GIANNINI, 1991). Entre os Karitiana, como em inúmeras cosmologias sul-americanas, o sangue é um fortíssimo agente corruptor da pessoa, e todo contato com sangue de outrem deve ser rigorosamente evitado. Há fortes indícios de que o cheiro do sangue é também deletério e potencialmente perigoso, aparentemente pela mesma razão que torna alguns animais malcheirosos e vedados ao consumo: o sangue humano também tem um cheiro forte, também tem pitiú - ge opira (catinga do sangue) ou ge bydnyda (fedor do sangue). 0 comentário Karitiana, evocado no início deste texto, acerca do cheiro do sangue coalhado, que na guerra sobe ao céu e tem poderes destrutivos, pode indicar o mesmo processo, tanto mais porque certas folhas (também gopatoma, remédio) devem ser colocadas nos túmulos para que o sangue dos mortos "não contamine as pessoas". Parece haver, ainda, uma relação entre o sangue dos indivíduos que morrem e sua "devolução" ao sol/céu maléficos; Shepard Jr. (2004) sobre a importância dos odores para a definição dos pares doençaplanta curativa, entre os Yora e Matsigenka, Peru; Cormier (2006) a respeito do uso de plantas perfumadas contra os perigos deletérios associados ao cheiro pútrido dos espectros dos mortos. Este acento colocado nas percepções olfativas pode parecer estranho para nós que, no ocidente, nos acostumamos a enfatizar a visão como órgão privilegiado de apreensão do mundo; isso pode explicar, ainda, a razão por que existem tão poucos estudos sobre o olfato na antropologia, uma vez que se trata de um dos sentidos mais importantes para numerosas cosmologias. Corbin (1987), em sua deliciosa história do olfato na Europa dos séculos XVIII e XIX, discute a questão, e recorda a antiga associação entre a malária e os "maus ares" dos pântanos e águas estagnadas. 
- que se tornam avermelhados, quando de cada morte ou nascimento na aldeia - em um vasto circuito de trocas cósmicas (VELDEN, 2004, p. 149-159), o que poderia explicar o fato de que o sangue produzido na guerra "sobe ao céu" junto com a fumaça: o céu/sol "chupa" o sangue dos mortos, avermelhando-se também porque raivosos com a morte, envergando o cocar de penas de arara vermelha característico dos guerreiros homicidas do passado (VELDEN, 2011).

Quanto ao cheiro da fumaça, estamos mais próximos das questões que pretendo explorar neste artigo, pois ele permite articular a percepção e a posição simbólica dos odores para as cosmologias indígenas na América do Sul e suas teorias a respeito dos brancos e do contato. Há alguns indícios etnográficos de que a fumaça produzida nas aldeias antes do contato - por exemplo, a fumaça produzida por uma peça de carne sendo assada no fogo (GIANNINI, 1991, p. 165; LIMA, 2006, p. 135, 145) - possa ser veículo de doenças. De qualquer modo, odores não familiares, de intensidade incomum ou presentes em contextos impróprios, são indicadores significativos da presença de criaturas perigosas ou percepções deficitárias da realidade (CORMIER, 2006; KEIFENHEIM, 2002; SHEPARD JUNIOR, 2004). Não obstante, é nas teorias sobre o contato e a subsequente irrupção de novas e agressivas doenças e elevadas taxas de morbidade e mortandade, em sua articulação com as implicações simbólicas dos novos materiais e instrumentos ou máquinas recebidos e adotados pelos grupos indígenas, que os efeitos deletérios do cheiro da fumaça ${ }^{12}$ assumem crucial importância (BUCHILLET, 2002; ERIKSON, 2002, p. 191; LIMA, 1986, 2000; WRIGHT, 2002, p. 457). É o que demonstrou, por exemplo e de forma magistral, Bruce Albert (1992), quanto aos resultados devastadores advindos da "fumaça do metal", uma propriedade odorífica que os Yanomami atribuíam aos facões ou a outras peças metálicas recebidas ou subtraídas dos brancos, e que foi, posteriormente, estendida aos mais diversos artefatos produtores de fumaça (motores, automóveis, a faiscação do ouro com mercúrio). Albert demonstra como a presença destes bens industrializados - cada

\footnotetext{
${ }^{12}$ Incluindo a fumaça dos cigarros, introduzidos com o contato entre certos grupos indígenas que não cultivavam ou consumiam o tabaco. Relatos da Comissão Rondon afirmam que os índios - de um grupo Tupi-Kawahib contatado por volta de 1914 - ficavam tão irritados com a presença de fumantes que arrancavam os cigarros de suas bocas, provavelmente preocupados com os efeitos perigosos associados à fumaça e seu cheiro (apud MEIRELES, 1984, p. 80). Devo assinalar que não me refiro á fumaça do tabaco (e de outras plantas) e seu poderoso efeito medicinal e uso xamânico largamente difundido nas terras baixas. Parece, pois, haver diferentes qualidades de fumaça e de seus odores, questão que merece uma análise comparativa mais detalhada, o que não tenho espaço para fazer aqui.
} 
vez mais abundantes ao longo da história recente dos Yanomami - se articula à teoria etiológica deste grupo indígena, assim como a sua visão do contato com os brancos.

Neste sentido, a caracterização dos novos odores apresentados com e após o contato com os brancos (como a fumaça dos combustíveis fósseis ou das bombas e armas de fogo, por exemplo) pelas diferentes cosmologias indígenas, e sua vinculação às alterações catastróficas promovidas no meio ambiente e nas condições sanitárias das populações - e também, não menos importante, na qualidade das relações de sociabilidade entretecidas no interior dos grupos ou entre grupos distintos - sugerem a aplicação daquilo que Glenn Shepard Junior (2004, p. 264) chamou de uma "ecologia sensorial" (sensory ecology). Esta abordagem privilegia a análise de redes orgânicas de interação entre plantas, animais, humanos e espíritos (e de todo o universo em geral) mediadas pelas sensações (SHEPARD JUNIOR, 2004, p. 255). No caso em tela, destacamos a importância do olfato, da percepção dos odores, para a compreensão das mudanças desastrosas ocorridas na história recente dos Karitiana. Poderíamos, eventualmente, alargar o escopo desta investigação para incluir, da mesma forma, os modos como os Karitiana traduzem sua experiência traumática do contato por meio de sensações gustativas, auditivas ou táteis (SHEPARD JUNIOR, 2004, p. 252-253).

Entre os Karitiana, como visto, a fumaça é considerada agente poderoso da propagação de doenças, sobretudo das graves enfermidades introduzidas após a chegada dos brancos ${ }^{13}$. No caso da conjuntivite que acometia a aldeia Kyõwã ao mesmo tempo em que estourava o conflito no Oriente Médio, o pensamento Karitiana associou o cheiro do sangue dos corpos mortos e a fumaça das explosões - ambos agentes patogênicos e deletérios - com os ventos que, segundo os conhecimentos geográficos deste povo, correm por todo o globo transportando substâncias e poderes, aqui deletérios. Tristes por conta da guerra - conforme várias pessoas verbalizavam na ocasião - os Karitiana também se viam preocupados com uma espécie de desequilíbrio na ordem do mundo, em tudo similar ao evento da abertura da estrada que conectou a aldeia ao universo dos brancos e abriu caminho para a penetração da fumaça destrutiva produzida nas cidades e fazendas. Para a doença local buscavam uma explicação global,

\footnotetext{
${ }^{13}$ Os Karitiana dizem que o produto aspergido na aldeia para o combate aos mosquitos - na forma de fumaça - mata suas galinhas, embora isso seja veementemente negado pelos funcionários brancos que realizam o trabalho.
} 
mas o inverso também parece ser verdadeiro: uma explicação local de uma doença de origem e efeitos globais.

0 que me interessa aqui é esta percepção que inter-relaciona os discursos sobre a doença e aqueles sobre as modificações destrutivas provocadas no meio ambiente após o contato e até os dias de hoje. Ao conceber seu quadro etiológico pós-contato como resultante da devastação ambiental, os Karitiana - assim como os Yanomami (ALBERT, 2002, p. 248-252), os Xokléng (WIIK, 2001), entre outros (SZTUTMAN, 2005) - sugerem estar operando, a partir de suas próprias categorias, conexões entre seus cotidianos locais e contextos globais de interação entre índios, brancos e diversos outros agentes, incluindo-se as políticas indigenistas, moralidades, o meio-ambiente e o ambientalismo. A atenção aos eventos ocorridos no Iraque pelos Karitiana aponta para o reconhecimento de que eles estão inseridos em uma ordem mundial que os afeta diretamente ali, nas suas aldeias encravadas na floresta amazônica. Os efeitos da Guerra do Iraque se fazem sentir em toda parte, ao serem pensados pelos Karitiana a partir de seus conhecimentos da geografia do cosmos, da dinâmica dos ventos e dos mecanismos da doença associada à fumaça e ao cheiro do sangue. Se uma borboleta batendo asas no Pacífico pode provocar tufões do outro lado do planeta, a fumaça produzida nos bombardeios das cidades iraquianas pode trazer a conjuntivite (e outras enfermidades) até os Karitiana.

Estas reflexões Karitianas nos propõem um desafio: como compreender as preocupações indígenas que articulam, entre outras coisas, saúde e meio ambiente, local e global, doença e história, de uma perspectiva culturalmente sensível? Ao conceberem, partindo do que assistiram na televisão, uma ampla circulação da fumaça pelo planeta, viajando de um lugar a outro por meio dos ventos - ao ponto de a fumaça produzida pelas bombas no Oriente Médio poder trazer doenças até sua aldeia no sudoeste amazônico -, os Karitiana nos colocam uma tarefa adicional: como dar conta de uma consciência cada vez mais abrangente, que sugere interseções complexas entre a saúde e as condições de vida locais e diversos problemas de dimensões globais? 0 que fazer quando o discurso sobre a saúde e a doença acaba, parece, por se interpenetrar e se fundir com reflexões ecológicas e de críticas ambientalistas?

\section{Etiologia e Ecologia}

0 nexo entre as condições de saúde de uma população humana e suas relações com o meio ambiente e outros seres vivos é reconhecido há pelo menos 
um século, sendo objeto clássico dos estudos da epidemiologia e do sanitarismo, e ensejando várias ações importantes em saúde pública, como o saneamento básico e o combate a zoonoses (UJVARI, 2004; para uma abordagem bastante didática e abrangente). Entretanto, cabe perguntar qual o estatuto da relação entre estas vertentes do pensamento biomédico e as sociedades indígenas, ou seja: ao concentrarmos nossa atenção no nível da interface entre os saberes, procedimentos e agentes médicos ocidentais e as cosmologias indígenas, como compreender a relação, entretecida pelos índios, entre suas condições de saúde e sua relação com o meio ambiente, em particular no contexto atual de devastação de florestas e degradação ampliada dos ecossistemas?

0 conhecimento dos saberes etiológicos indígenas e a compreensão detalhada da interface entre medicinas tradicionais e a medicina biomédica/ ocidental devem ser alargados, de modo a abranger outras relações cujo funcionamento é crucial para os estados de saúde e doença de uma população. Penso aqui, particularmente, nas relações entre os humanos e o que chamamos de meio ambiente (ou natureza), ou seja, os elementos, poderes e os outros seres vivos e agências que povoam o universo. Como vimos no caso dos Karitiana, as doenças reconhecidamente agressivas são o resultado de relações desequilibradas entre os humanos e o meio que o circunda, tematizadas ali como em outras cosmologias, através da crítica à devastação da floresta e à produção exagerada da fumaça por parte dos brancos, que exercem efeitos destrutivos sobre os humanos. Uma moralidade também se encontra envolvida nas considerações dos Karitiana a respeito das mortes provocadas pela guerra do Iraque e no excesso de sangue derramado e tornado fumaça a partir de seu cheiro: esta, como veremos, pode ser também tomada como uma crítica ambiental, pois associa, por meio da moral, a devastação da natureza ao comportamento agressivo, ganancioso, predatório e egoísta dos brancos.

Faz-se necessário, portanto, uma detalhada compreensão das relações apropriadas entre humanos e outros seres animados ou inanimados, posto que estão diretamente relacionadas às condições de saúde e bem-estar. Isso significa que é fundamental dar atenção para espaços de vivência cotidiana destas populações que não estão, aparentemente, relacionadas aos problemas de saúde. As relações apropriadas com o meio ambiente são um deles. Meio ambiente é entendido em sentido amplo ${ }^{14}$, o que inclui as interações entre seres humanos e outras seres

${ }^{14}$ Note-se que, aqui, estou fazendo uso de uma categoria - ambiente ou meio ambiente - cujo 
vivos, fenômenos climáticos, acidentes geográficos, e mesmo entidades não reconhecidas pelas ciências ocidentais, mas cuja presença e ação são fundamentais para a compreensão detalhada dos cenários cotidianos das populações indígenas sul-americanas, tais como os espíritos, os mortos, as criaturas monstruosas ou bichos, as divindades, entre outros. Nesse sentido, a percepção da fumaça e de seu cheiro como agentes corruptores da saúde e da pessoa são índice seguro da relação entre as agressões ao meio ambiente (queima e derrubada de florestas e poluição do ar, mas também represamento de rios, contaminação de águas e solos em geral, acúmulo de lixo, e daí por diante) e as condições de existência das sociedades indígenas.

Da mesma forma, existem as relações mais específicas, entre os humanos e as plantas (FARAGE, 1997) e, sobretudo, aquelas entre os humanos e os animais, "domésticos" (animais familiares ou, como dizem os Karitiana, animais de criação) ou "silvestres" (animais do mato, para os Karitiana). Quanto a este último ponto, destaque-se que muito da literatura etnográfica das terras baixas sul-americanas já demonstrou o laço que une os excessos na caça (abater animais além da necessidade, abater e consumir certas espécies animais, lidar com a carcaça do animal morto e seus despojos de maneiras consideradas impróprias, exageradas e/ou abusivas) com as doenças ou os estados alterados da pessoa: desequilíbrios físicos e emocionais, demência, antisocialidade, morte (CUNHA; ALMEIDA, 2002, p. 311-335; FARAGE, 1997; GIANNINI, 1991; KENSINGER, 1995, p. 208, 248; POSEY; ELISABETSKY, 1991; REICHEL-DOLMATOFF, 1976, 1985). Do mesmo modo, várias etnografias assinalam uma "função profilática" vinculada aos cuidados domésticos para com alguns animais, o oposto simétrico da predação cinegética cuja consequência é, via de regra, a quebra da reciprocidade e a vingança na forma da doenças enviadas pelos animais (ERIKSON, 2000; REICHEL-DOLMATOFF, 1968). Assim, assinalamos que é vital que a reflexão sobre a saúde indígena esteja atenta para o conjunto das relações entre os humanos e outros seres, pois muitas das doenças reconhecidas pelas culturas indígenas são resultados diretos da vingança de outros seres (dos próprios animais ou dos seres,

sentido existe para a ecologia ocidental, e não dá conta dos modos culturalmente distintos e diversificados por meio dos quais as sociedades indígenas descrevem o universo (DESCOLA, 1996; CASTR0, 1996). Não obstante, o que este texto sugere, fazendo eco a vários outros estudos, é uma apropriação da categoria por parte de numerosos grupos indígenas, cujo efeito é a criação de espaços comuns de argumentação, ainda que esta "indigenização" do conceito mereça, sempre, análise cuidadosa e etnograficamente fundamentada de seus novos significados. 
muito comuns nas terras baixas sul-americanas, conhecidas como "mestre", "chefe", "senhor" ou "dono" da caça ou de tal ou qual espécie) em função de agressões sofridas da parte dos homens (BARROS, 2003, p. 175, 266; OVERING, 1985a, 1985b).

0 par saúde/doença se encontra, então, intimamente relacionado às condições ambientais e às relações entre seres humanos e não-humanos, pois um equilîbrio é sempre necessário, ainda que devemos qualificar modos culturalmente específicos deste "equilíbrio". No entanto, as formas capitalistas de apropriação predatória e perdulária dos recursos naturais destroem este balanço, trazendo como uma de suas conseqüências a doença. Vejamos o comentário de um xamã Kayapó-Xikrin, que articula os temas que aqui tratamos - contato, degradação ambiental, doença - e que responde a uma série de epidemias intermitentes de diarreia e pneumonia:

"Todo mundo tá doente, é kaprem [feitiço] de Akrãre [ser sobrenatural, dono-controlador dos animais da floresta], kuben (não-índio) tá desmatando tudo." (GIANNINI, 1991, p. 162).

Temos, portanto, o seguinte cenário:

A origem de uma doença entre os povos indígenas pode muitas vezes ser encontrada na relação entre o ser humano enfermo e partes da natureza, tais como plantas e árvores, ou mesmo fenômenos como ventos ou remoinhos de água. Hoje em dia, esse tipo de explicação pode ser estendido e incluir fenômenos "modernos", como aviões passando no céu e gases de combustão - contaminações (FÓLLER, 2004, p. 136).

Note-se que este comentário coloca em evidência outra questão importante, que remete à percepção indígena das relações entre os seres humanos e o universo: trata-se da articulação entre a degradação do ambiente e das espécies "naturais" e o aparecimento dos brancos. Aqui, o nexo entre o contato e a deterioração das condições de saúde das populações indígenas se evidencia totalmente: os brancos trazem as doenças bravas, graves, agressivas, mas este processo deve muito à compreensão dos recém-chegados como seres que não estabelecem, eles sim, relações medidas e apropriadas com o meio ambiente e as demais espécies, e muito menos com outros humanos, os índios. Produtores de fumaça em demasia, incontrolavelmente móveis e assustadoramente multiplicáveis, senhores de objetos 
estranhos que se revelam, em muitos casos, destrutivos ou mortais (ALBERT, 2002). Como bem observou Dominique Buchillet:

As sociedades indígenas, muitas vezes, associam as devastadoras epidemias à tecnologia ocidental; ambas manifestam um tipo de poder "sobrenatural", ou "mágico" dos brancos. Embora a natureza exata desse poder jamais tenha sido explicitada pelos antropólogos, fica claro que, para os Desana, tal poder - manifesto na aparente intimidade dos brancos às doenças infectocontagiosas, na sua densidade demográfica, na sua habilidade técnica e também na sua opulência - fundamenta-se na exorbitante capacidade de reprodução e disseminação dos brancos e de suas posses (objetos, doenças) e só parece capaz de se expressar à custa da própria existência dos índios. (BUCHILLET, 2002, p. 130-131).

Outro exemplo interessante do nexo entre contato e degradação ambiental, odores, doença e morte vem dos Awá-Guajá, povo Tupi-Guarani no oeste do Maranhão. Com efeito, Loretta Cormier encontrou em sua pesquisa com este povo o conhecimento sobre uma grande quantidade de plantas cujo cheiro pungente e perfumado é utilizado profilaticamente contra os fantasmas dos mortos, caracterizados pelo odor fétido cujo efeito sobre os vivos é a predação canibal e a morte (CORMIER, 2006, p. 129-131). Explorando as diversas conexões possíveis diante deste cenário em que se articulam conhecimentos etnobotânicos, práticas terapêuticas, manifestações psicofisiológicas e descrições cosmológicas, a autora nos conduz ao ponto de encontro entre a história dos Awá-Guajá, suas teorias etiológicas e procedimentos profilático-curativos e o meio ambiente que os cerca, afirmando que o elevado número de plantas destinadas à proteção contra espectros malcheirosos conhecidas pelo grupo tem relação direta com as elevadas taxas de mortalidade que acompanharam as devastadoras epidemias introduzidas pelo contato. Tendo produzido uma enorme quantidade de mortos-fantasmas - e também, consequentemente, de sofrimento-saudade -, as novas doenças trazidas pelos brancos impulsionaram o interesse nas plantas odoríferas cuja função principal é fazer desaparecer a presença ameaçadora dos mortos (CORMIER, 2006, p. 134). Cormier propõe, portanto, uma ecologia da doença, ao demonstrar a importância das relações entre a história do contato, das teorias etiológicas e das interações entre populações humanas e não-humanas em determinado ecossistema (CORMIER, 2006, p. 143-146) ${ }^{15}$.

${ }^{15}$ Embora Cormier não nos dê indícios a respeito, podemos supor que o balanço das relações 
A doença, pois, articula a história do contato (degradação dos corpos, quase extinção física dos grupos, encontro com brancos moralmente falíveis e comportamentalmente estranhos, agressivos e perturbadores) e a degradação ambiental (rastro de destruição provocado pelo homem que chega até as aldeias abrindo caminho através da mata, trazendo a fumaça produzida nas cidades e nas guerras, levando a doença pelo mundo afora) em um discurso que fala, sobretudo, da desigualdade brutal entre índios e brancos. A relação, via de regra violenta, entre uns e outros espelha a relação doentia entre os brancos e o meio ambiente. A história de vários grupos indígenas, como a dos Karitiana, é pensada pelos próprios índios em termos de saúde e doença: memória inscrita nos corpos indígenas, corpos que são, hoje, índice visível desta história trágica; eles são como que um precipitado da trajetória do contato, feita de doença e morte, destruição ambiental e violência, fumaça e sangue. A compreensão desta trajetória, assim como seu resultado atual, não pode deixar de ser incorporada na compreensão do que é a saúde indígena (ou, do que são as saúdes indígenas culturalmente singulares). Como observa Flávio Wiik (2001), o entendimento dos processos corporais, saúde e doença, deve passar, necessariamente, pela observação do conjunto de "fatores concretos externos" que influenciam diretamente a vida destas populações, sobretudo tendo-se em vista o imenso impacto demográfico e sanitário que enfrentaram após o aparecimento dos brancos:

Isto faz com que corporalidade e estados corporais degenerativos, sociedade - através de seus agentes sociais - e agentes externos macroconjunturais [que, nesta etnografia, são, por exemplo, a construção de barragens, a invasão de terras, a exploração desenfreada de recursos naturais, a mercantilização e a monetarização agressivas das relações] formem uma tríade interligada (WIIK, 2001, p. 400, grifo do autor).

entre plantas-perfumadas-protetoras e espectros-fétidos-agressivos foi perturbado, sobretudo, pela irrupção de novos odores trazidos pelos brancos, tal como o cheiro da fumaça. Digo isso porque 0 material Guajá, apresentado pela autora, tem muita semelhança com o dos Karitiana que discuti acima e alhures (VELDEN, 2004), incluindo-se os banhos profiláticos com infusões de plantas (CORMIER, 2006, p. 130-131). Entre os Karitiana, estes banhos servem para repelir as doenças bravas, cuja origem está na abertura do "canal" entre a aldeia e a cidade, e que teria permitido a passagem de grande quantidade da fumaça com efeitos deletérios; faltaria investigar, contudo, se também entre os Karitiana o uso destes banhos profiláticos com plantas registrou aumento após o contato. 
Tríade que integra e articula as noções singulares de saúde e doença com as concepções indígenas das relações sociais e interpessoais e do universo (algo que vagamente definimos como meio ambiente) em que vivem e com 0 qual interagem. Isso implica, evidentemente, na tomada de consciência de que a saúde e o bem-estar são consequências diretas das boas interações entre humanos, animais, plantas e o ambiente que constroem e onde interagem. Ou seja, daquilo que Edir Pina de Barros (2003, p. 287) chama de uma ética socioecológica entre os Bakairi.

As interconexões entre a saúde e o meio ambiente ressaltam também, de formas variadas, na sugestão de que as doenças podem agir como "mecanismo de controle ecológico" (POSEY; ELISABETSKY, 1991), uma vez que, para os Kayapó, numerosas doenças têm sua origem na relação desequilibrada entre seres humanos e não-humanos. Procedimentos de controle da caça excessiva e do abuso para com as presas abatidas - associados aos diversos interditos rituais, aos esquemas classificatórios e ao conhecimento das espécies animais e vegetais e dos ambientes em que vivem, que regulam que "tipos" de seres podem ser abatidos/ consumidos, e em que quantidade - parecem ter impacto direto na ecologia das diferentes espécies nos meio ambientes explorados pelos Kayapó, impacto no mais das vezes favorável à preservação destas espécies e do balanço ecológico de uma regiã $0^{16}$. Associado a estes procedimentos - cujo impacto "ecológico", destaquese, procede da percepção dos pesquisadores - estão muitas doenças relacionadas à vingança dos animais, se explorados de modo desordenado e descompromissado, o que permite perceber, novamente, as estreitas imbricações entre saúde e ambiente. Assim:

"A boa saúde depende da harmonia entre as forças da natureza em geral, e o equilibrio entre os espíritos dos homens e animais em particular." (POSEY; ELISABETSKY, 1991, p. 31).

Teorias indígenas sobre a doença, portanto, articulam um conjunto de fatores que extravasam os limites impostos pelas noções biomédicas da enfermidade, mesmo daquelas que atentam para a relação entre saúde e ambiente. Relações entre seres humanos e não-humanos, odores perfumados ou

\footnotetext{
${ }^{16}$ Note-se que este mecanismo, aparentemente, não parece poder ser generalizado: Coelho (1995, p. 269, nota 2) observa que os Waurá, apesar de temerem as "represálias" dos animais que matam, "não deixam de agredir o meio ambiente"; o temor da vingança não os impede de ter "alto poder de destruição", e "não serve como inibidor da destruição da natureza [sic] e não gera uma atitude ecologicamente correta".
} 
nauseabundos, devastação ambiental, relações sociais presentes e históricas entre índios e brancos, tudo isso integra a noção Karitiana da doença, efeito-espírito manifestado no ou transportado pelos ares e ventos, nas aldeias e mundo afora. Em termos de sua teoria etiológica, portanto, os Karitiana tecem comentários a respeito de fenômenos que, para nós, são de outra natureza e, potencialmente, falam não só para uma audiência aldeã, mas se convertem em discurso de alcance global. Local e global se interpenetram no modo como os Karitiana compreendem a lógica das moléstias que ameaçam a vida no planeta.

\section{DO LOCAL AO GLOBAL, E VICE-VERSA}

0 interesse dispensado pelos Karitiana aos confrontos bélicos no Oriente Próximo não foi exclusiva entre os povos indígenas amazônicos, demonstrando, uma vez mais, a alta difusão midiática do evento e sua penetração em diferentes contextos sociais mundo afora. Gabriel Alvarez (2009, p. 90-91), por exemplo, documentou que os Sateré-Mawé, atentos ao desenrolar dos fatos em 2003, comparavam um de seus personagens míticos, o Chefe da Flecha, que vivia oculto, a Saddam Hussein, demonstrando "a dimensão global que adquiriu o conflito" e sugerindo que os Sateré-Mawé "tinham a Guerra do Golfo como parâmetro para explicar as guerras míticas”.

Há, não obstante, uma diferença fundamental entre os efeitos provocados pela guerra entre os Sateré-Mawé e os Karitiana. Lá, as imagens da guerra e os discursos sobre ela e sobre seu mais polêmico ator (o então presidente iraquiano Saddam Hussein) que circulavam amplamente foram tomados como modelo para explicar ao etnólogo as atitudes de uma figura mítica; os efeitos foram, por assim dizer, indiretos. Aqui, as mesmas imagens e discursos televisivos levaram à formulação de explicações Karitiana para efeitos diretos que os combates estavam provocando na Amazônia: doenças trazidas pelo vento que transportava, em escala mundial, o sangue e a fumaça das bombas e campos petrolíferos em chamas. Entretanto, as categorias do sistema cosmológico Karitiana acionadas para constituir o vínculo entre a Guerra do Iraque e um episódio epidemiológico na sua principal aldeia podem lançar luz, como vimos, aos modos como este povo indígena concebe a história do contato com os brancos, em uma articulação complexa entre doença, degradação ambiental e moralidades duvidosas. 
Areflexão Karitianasobre um evento de impacto global permite compreender algo de sua teoria etiológica, baseada nos espiritos ou bichos (psam'em) que se manifestam pelo vento e que com ele carregam odores mefíticos, cujo contato com as pessoas provocam a doença e podem levar à morte. 0 que é interessante apontar aqui é a possibilidade, aos olhos Karitiana, de que a manifestação da enfermidade seja provocada por ações transcorridas em local tão distante de seu território e, mais, que processos que poderíamos dizer climáticos - a movimentação global dos ventos - sejam levados em conta para explicar esta conexão iraquianoamazônica. Além disso, a crítica à guerra e às mortes de soldados e civis - feita a partir do temor da abundância de sangue e de fumaça - sinaliza a observação atenta dos Karitiana não apenas ao modo destrutivo como os brancos vêm tratando o meio-ambiente, mas também aos discursos que os mesmos brancos têm produzido para tentar conter este processo acelerado de devastação: a ecologia ou 0 ambientalismo.

0 ambientalismo tem sido, nos últimos tempos, um discurso forte de apelo global, em especial no que se refere à Amazônia, devido a sua extensão, ao tamanho de sua biodiversidade e à complexidade dos serviços ambientais que fornece, de "pulmão do mundo" (RIBEIR0, 1990). Discurso englobante a estruturar as regras do discurso político mundial hoje (ALVAREZ, 2009, p. 137): "[...] o discurso ecológico fornece hoje os principais paradigmas de construção da cidadania [...]” (PERES, 1999, p. 211). Evidentemente, as sociedades indígenas na Amazônia perceberam, desde os anos de 1980, a penetrabilidade do discurso ambiental e ecológico na população global, e as maneiras através das quais esses discursos podem ser convertidos em forças de apoio às reivindicações indígenas ou traduzidos em recursos que podem se apropriados localmente. Segundo Bruce Albert, ocorreu uma "ecologização' do discurso político" indígena (ALBERT, 2002, p. 240; TURNER, 1991). Muito se discute, ainda, se os povos indígenas são ou não são ecologistas, no sentido estrito do termo, conservacionistas natos dos ecossistemas, das paisagens e das outras formas de vida (DESCOLA, 1998; PERES, 1999). Contudo, não é isso que está em questão aqui, mas as modalidades de apropriação desse discurso ambientalista por parte dos índios, os modos como eles são relidos por lógicas cosmológicas indígenas, e quanto esta releitura nos pode ajudar a compreender essas mesmas lógicas e seu funcionamento no mundo contemporâneo, nos níveis local e global. 
Um dos primeiros povos indígenas a perceber esta conexão sensível - à mídia e aos olhos ocidentais - entre a natureza e as populações tradicionais foram os Yanomami na fronteira do Brasil com a Venezuela, cuja voz podemos ouvir a partir do poderoso trabalho de antropologia dialógica e simétrica efetivado entre um grande líder e xamã deste povo, Davi Kopenawa Yanomami, e 0 antropólogo francês Bruce Albert (ALBERT, 2001, 2002). Em um conhecido texto, Albert analisa as reflexões de Kopenawa a respeito da devastação da floresta levada a cabo por garimpeiros no território Yanomami, articulando muitos dos pontos também tematizados pelos Karititan em seu comentário sobre a fumaça oriunda do Iraque. Com efeito, Kopenawa afirma que a fumaça produzida pelos incêndios florestais e pela queima do amálgama ouro-mercúrio para a obtenção das pepitas nos garimpos atinge "o mundo inteiro", e o vento a leva até 0 "peito do céu" que, então, "morre de epidemia" (ALBERT, 2002, p. 252). Uma vez morto, o céu desabará sobre a Terra, causando a morte de todos os seres e 0 fim da humanidade, e apenas o trabalho incessante dos xamãs Yanomami pode evitar que este cataclisma ocorra, a não ser que os brancos cessem suas agressões contra o planeta. Desta forma, Albert sugere que esta reflexão dos Yanomami sobre o contato, o convívio com os brancos destrutivos e seus efeitos se configura no que ele chamou de uma "crítica xamânica da economia política da natureza" (ALBERT, 2002) - um discurso político fortemente entretecido nas (mas nunca idêntico às) retóricas ambientalistas e ecológicas contemporâneas, e que articula habilmente conceitos e práticas vinculados às teorias etiológicas e à visão da história do contato dos Yanomami com preocupações candentes na ordem do dia da política internacional. De fato, Davi Yanomami é uma liderança sagaz. Contudo, não é apenas de esperteza, cinismo ou de estratégia que falamos aqui (ALBERT, 2002, p. 241); ao contrário, importa focalizar as maneiras de encaixar estes discursos nativos no mapa dos debates mundiais sem reduzi-los à sagacidade de seus formuladores ou a meros simulacros folclóricos dos dados científicos produzidos localmente e, por isso, sem maior impacto global.

Albert (2002, p. 243) sugere que o que Davi Kopenawa e os Yanomami estão fazendo é uma antropologia reversa, expressão cunhada por Roy Wagner (2010), para dar conta das formas de reflexão e dos discursos produzidos por populações nativas a respeito da(s) sociedade(s) de onde provêm seus antropólogos. Davi Yanomami, em seu discurso, logra articular política (branca) e cosmologia (que é, também, evidentemente, política): 
O que Davi revela por trás da ignorância dos "comedores de terra-floresta" [os garimpeiros] é a relação cosmológica entre a extração de ouro nas terras yanomami e as epidemias que despovoam a floresta (ALBERT, 2002, p. 249).

E, ainda, mais importante, local e global, a Amazônia e o planeta, flexionando, de uma forma propriamente Yanomami, os discursos ambientalistas. Nas palavras do próprio Davi:

Esta fumaça-epidemia [a fumaça produzida nos garimpos, mas também nas máquinas e fábricas dos brancos] atinge o "mundo inteiro"... 0 vento leva-a até 0 céu. (ALBERT, 2002, p. 252).

Desta forma, o discurso que focaliza, inicialmente, os impactos da presença destruidora dos brancos em aldeias amazônicas isoladas, converte-se, poderosamente, em um comentário sobre os brancos como um todo e sobre sua sociedade industrial predatória e produtora abundante de fumaça que, tal qual uma epidemia, "fura o peito do céu", matando-0. Aqui, no entanto, estamos diante da reflexão de um grande líder e excepcional mediador interétnico. 0 caso Karitiana, no qual não há uma figura de destaque, mas que também se revela um comentário perspicaz sobre os brancos (e o que estão fazendo com o planeta), assemelha-se ao caso da luta do povo Yonggon na Nova Guiné contra a gigantesca mina de ouro e cobre de 0k Tedi, analisado magistralmente por Stuart Kirsch (2006).

Kirsch (2006, p. 35-36) argumenta que a ideia de regiões isoladas e desconectadas do restante do planeta não faz sentido, pelo menos desde o século XVI: eventos de escala local estão necessariamente vinculados a movimentos de nível global, ambos constituindo-se a afetando-se reciprocamente. Mais do que isso, 0 autor defende que as formas Yonggon de constituir o mundo e sua relação com ele e os seres humanos e não-humanos que o habitam são, em si mesmas, formas de análise ambiental (KIRSCH, 2006, p. 57-78). Estas concepções permitem aos Yonggon refletirem sobre impactos ambientais na sua região e, mais ainda, criticarem-nos fortemente a partir de seu próprio arsenal mítico e cosmológico. Este arsenal local, articulado ao diálogo dos Yonggon com atores em outras esferas políticas e sociais internacionais, permite a eles sustentarem que a poluição não se restringe a sua região em particular, mas se espalha por todas as partes do mundo de forma sistêmica (KIRSCH, 2006, p. 199). Além disso, as formas de degradação ambiental que eles experimentam localmente - a extrema poluição do rio $0 \mathrm{k}$ Tedi pelo enorme empreendimento minerador - são, na verdade, um espelho da 
falência geral da humanidade em constituir relações sociais apropriadas - pois a poluição é uma relação social, uma troca malfadada, pois a mina, enquanto um agente (STRATHERN, 1999, p. 229-233), apenas extrai dos Yonggon e de seu território, nada lhes dando em troca (KIRSCH, 2006, p. 106) - e, a partir delas, garantir a sobrevivência de todos em um ecúmeno global saudável e rico (KIRSCH, 2006, p. 197-200).

Penso que são conexões como estas, feitas pelo líder-xamã Davi Kopenawa Yanomami e pelos Yonggon, que os Karitiana estão fazendo quando o odor da fumaça das bombas e do sangue derramado no Iraque viaja pelo mundo e chega à Amazônia na forma de epidemias. É isto, de fato, que os brancos sabem fazer: com sua atitude devoradora e excessiva diante do mundo, produzir fumaça em abundância cujo cheiro é uma das causas maiores das doenças, que estão por toda parte. Só não concordo com Stuart Kirsch na sua leitura de Ulrich Beck, ao argumentar que os Yonggon não têm clareza sobre a ação dos poluentes no meio e nem sobre os riscos que eles colocam para os seres do mundo (KIRSCH, 2006, p. 199). Penso que as formas nativas de análise ambiental são, como o próprio autor propõe, formas de conhecer o mundo mesmo em radical transformação. Não há, portanto, necessidade de um apelo à ciência (ocidental) para explicar a poluição, posto que a cosmologia Yonggon já oferece os recursos para isso: os Yonggon pensam, como todas sociedades humanas, o mundo, que é seu mundo. É bem o que ilustra Bruce Albert (2002, p. 252) ao demonstrar como Davi Yanomami explora a semântica dos conceitos nativos de modo a ler a poluição a partir da chave das doenças epidêmicas.

Os Karitiana fazem a mesma coisa ao pensarem a poluição e a guerra como origem das epidemias, bem como o alastramento global de eventos locais: a fumaça (a poluição), assim como a doença - e, ao fim e ao cabo, os próprios homens brancos em sua capacidade multiplicadora de mercadorias e de si mesmos - não têm limites. Esta é uma percepção feita em termos de sentidos: são os odores fétidos da fumaça e do sangue, os índices mais confiáveis de que estes carregam efeitos-espírito que causam doenças. Assim, a afirmação de Beck (2010) - de que um dos efeitos do risco ambiental produzido pela industrialização é fazer com que nossos sentidos percam a capacidade de nos fornecer informações adequadas acerca do meio ambiente - parece não se aplicar aqui: é pelo nariz que os Karitiana detectam a fumaça-doença. É por meio dele que percebem, a partir de suas pequenas aldeias situadas num remoto canto da Amazônia brasileira, que 
algo está errado neste mundo em que os ventos só fazem transportar, do Iraque para cá, e daqui para lá, o cheiro doentio do contato.

\section{Considerações Finais}

No mundo globalizado de hoje as informações circulam em velocidades espetaculares, e chegam até os locais mais distantes. Não é diferente com os povos indígenas no Brasil: através da televisão - meio cada vez mais difundido - estas sociedades têm a sua disposição um conjunto enorme e diversificado de informaç̧ões provenientes de todos os cantos da Terra. Frequentemente, a recepção destas informações, como sempre acontece, gera reflexões e comentários que as articulam a sentidos cosmológicos particulares, gerando teorias que buscam dar conta, cada vez mais, da percepção, por parte das comunidades indígenas atuais, de que elas são parte de uma ordem global que vai muito além dos segmentos das sociedades nacionais com os quais mantêm contatos diretos.

Este cenário tem sido particularmente observado no que diz respeito ao desejo de integração política entre as populações indígenas de diversos países ou regiões de um mesmo país, e no tocante ao discurso ambientalista de cunho internacional. Quanto a este último ponto, nota-se que diversas sociedades têm formulado discursos próprios, paralelos ao discurso oficial, mas diferentes dele em incontáveis aspectos (ALBERT, 2002; DESCOLA, 1998, 2000; REICHEL-DOLMATOFF, 1976). Note-se, ainda, que muitas destas formulações "ecológicas" - como vimos, no caso dos Karitiana, dos Yanomami e dos Yonggon, entre tantos outros - trazem informaç̧ões relevantes para a compreensão dos modelos de relacionamento entre o que chamamos de meio ambiente e estados de saúde/doença, além de falarem da posição que os não-índios ocupam nos universos sociais e cosmológicos e nas trajetórias históricas desses povos.

0 que se propõe, neste artigo, é analisar o modo como duas ordens de explicações dos fenômenos, uma Karitiana e uma do ambientalismo ocidental contemporâneo, podem ser articuladas (posto que elas não são, de modo algum, mutuamente excludentes), a partir da percepção e dos comentários dos Karitiana sobre a relação entre degradação ambiental, história, relações sociais e saúde/ doença. Isso nos permite um diálogo produtivo entre os dois pontos de vista, na esteira daqueles encontros transculturais que Marshall Sahlins (1981) chamou de mal-entendidos produtivos, ou que Eduardo Viveiros de Castro (2004) definiu 
como método apropriado para a produção de conhecimento antropológico: 0 método da equivocação controlada, já aplicado por alguns autores na análise das interações político-discursivas e dos resultados ambíguos e contraditórios dos diálogos entre ambientalistas e povos indígenas (BLASER, 2009).

Os Karitiana, quando pensavam sobre os impactos dos subprodutos da Guerra do Iraque nas suas vidas cotidianas, não estavam dizendo a mesma coisa que os ecologistas, preocupados com os efeitos da fumaça na camada de ozônio da Terra e no efeito-estufa. No entanto, a reflexão dos índios sobre um fenômeno ocorrendo tão distante deles não deixou de, ao conectar dois lados do mundo, tornar-se prenhe de sentidos ali, nas suas aldeias. Assim é que o impacto da devastação ambiental e da poluição provocada pelo excesso de emissão de gases (fumaça) fez sentido para a teoria etiológica Karitiana, que coloca forte ênfase na circulação aérea das doenças e nos seus odores; assim, também, é que a importância atribuída à malária e outras doenças bravas (kida oti sara) pelos Karitiana pode ser correlacionada aos altos índices de prevalência destas moléstias entre eles (ESCOBAR et al., 2003) e na região norte de Rondônia em geral (PARAGUASSU-CHAVES, 2001). Da mesma forma, pode-se relacionar as doenças provocadas pela "vingança" dos animais submetidos aos excessos da predação cinegética à percepção de que a caça está, efetivamente, diminuindo diante da forte pressão antrópica na região. Por último, sugere-se um paralelismo entre a percepção Karitiana da degeneração e da diminuição de seus corpos após o contato com os indicadores biomédicos de nutrição deficitária, altas taxas de moléstias infecciosas, taxas crescentes de doenças crônico-degenerativas, e assim por diante.

Impactos locais de acontecimentos (em outros) locais: o mundo globalizado de hoje mostra-nos isso, e ao pensarem nas e sobre suas aldeias os Karitiana como os Yonggon e os Yanomami - pensam o mundo. A fumaça das bombas e campos petrolíferos fumegantes vai "girando o mundo inteiro", espalhandose insidiosamente com os ventos, e "destruindo a ventilação da Terra". Ela traz doenças para as aldeias, e esta é a forma da experiência local de um evento muito maior, tanto climática quanto geopoliticamente.

Um evento que, para além de ambiental, adiciona comentários, do ponto de vista indígena, à lógica predatória da civilização industrial, que só produz guerra, sangue, fumaça, devastação ambiental e, ao fim e ao cabo, doença e deterioração corporal. Os Karitiana, assim como outros milhares de outros povos indígenas e tradicionais (WAWZYNIAK, 2004), estão a fazer uma antropologia reversa (ou, 
talvez, poderíamos dizer, também uma ecologia reversa), ao refletirem sobre como a moralidade dos brancos e seus modos perdulários de apropriação dos ecossistemas locais (incluindo-se, aqui, humanos e não-humanos, naturezas e sociedades) provocam alterações de alcance global, que são sentidas, também, ali no seu território: a fumaça e o sangue gerados no longínquo Iraque se fazem sentir na forma de doenças em Kyõwã, no sudoeste da Amazônia brasileira. Da mesma forma, o contato com os brancos é lido pelos Karitiana como uma história da destruição da floresta e da abertura de um caminho para as doenças novas que vêm, desde então, fragilizando e diminuindo os corpos dos índios. A teoria etiológica Karitiana pode ser tomada, desta forma, como um modo de análise (KIRSCH, 2006) de fenômenos de amplo alcance midiático como o aquecimento global (FAGAN, 2009) ou as "guerras climáticas" que já se manifestam neste século XXI (WELZER, 2010), pois as mudanças no clima, que afetam todo o planeta, também são percebidas e experimentadas pelos Karitiana - de formas singulares, logicamente - e estão na ordem do dia de suas preocupações, mesmo que seus discursos sobre elas, por serem formulados em termos nativos, não sejam de fácil acesso mesmo para os ecologistas (ALBERT, 2002).

Nas aldeias dos Karitiana, a fumaça que corre o mundo através dos ventos espalha as enfermidades, que incidem sobre os corpos indígenas, tornando-os fracos, doentios e vulneráveis. A guerra feita pelos homens brancos no Iraque chega aqui neste pedaço da Amazônia brasileira na forma de outros combates, levados a cabo pelas pessoas que, amargando cotidiana e ritualmente seus corpos, buscam repelir as moléstias e conter, assim, o avanço inexorável da civilização industrial. Civilização que é feita de doença e de devastação, de fumaça e de sangue.

\section{REFERÊNCIAS}

ALBERT, Bruce. A fumaça do metal: história e representação do contato entre os Yanomami. Anuário Antropológico, Rio de Janeiro, v. 89, p. 151-189, 1992.

. 0 ouro canibal e a queda do céu: uma critica xamânica da economia política da natureza. In: ALBERT, Bruce; RAMOS, Alcida (Org.). Pacificando o branco: cosmologias do contato no norte-amazônico. São Paulo: Imprensa Oficial/Edunesp/IRD, 2002.

. The rivers know our blood (interview with Davi Kopenawa Yanomami).

Cadernos da CCPY - Documentos Yanomami, Brasília, n. 2, p. 115-121, 2001. 
ALMEIDA, Alfredo Wagner Berno (Org.). Conflitos sociais no complexo madeira. Manaus: Edições UEA, 2009.

ALVAREZ, Gabriel. Satereria: Tradição e Política - Sateré-Mawé. Manaus: Editora Valer, 2009.

BARBR00K, Richard. Futuros imaginários: das máquinas pensantes à aldeia global. São Paulo: Fundação Peirópolis, 2009.

BARROS, Edir Pina. Os filhos do sol: história e cosmologia na organização social de um povo Karib: os Kurâ-Bakairi. São Paulo: Edusp, 2003.

BECK, Ulrich. Sociedade de risco: rumo a outra modernidade. Rio de Janeiro: Editora 34, 2010.

BLASER, Mario. La ontología política de un programa de caza sustentable. Red de Antropologías del Mundo - World Anthropologies Network, n. 4, p. 81-107, 2009 .

BORZACOV, Eduardo. Glossário do linguajar amazônico. Porto Velho: Edição do autor, 2004 .

BUCHILLET, Dominique. Contas de vidro, enfeites de branco e potes de malária: epidemiologia e representação de doenças infecciosas entre os Desana do alto Rio Negro. In: ALBERT, Bruce; RAMOS, Alcida (Org.). Pacificando o branco: cosmologias do contato no norte-amazônico. São Paulo: Imprensa Oficial/ Edunesp/IRD, 2002.

CASTRO, Eduardo Viveiros. Araweté: os deuses canibais. Rio de Janeiro: Zahar/ Anpocs, 1986.

. A inconstância da alma selvagem: e outros ensaios de antropologia. São Paulo: Cosac \& Naify, 2002.

. Indivíduo e sociedade no Alto Xingu: os Yawalapíti. 1977. Dissertação (Mestrado em Antropologia Social) - Universidade Federal do Rio de Janeiro, Rio de Janeiro.

. Os pronomes cosmológicos e o perspectivismo ameríndio. Mana, Rio de Janeiro, v. 2, n. 2, p. 115-144, 1996.

Perspectival anthropology and the method of controlled equivocation. Tipiti, Oxford, v. 2, n. 1, p. 3-22, 2004. 
COELHO, Vera P. Figuras zoomorfas na arte Waurá: anotações para o estudo de uma estética indígena. Revista do Museu de Arqueologia e Etnologia da USP, São Paulo, v. 5, p. 267-281, 1995.

COOK, Noble D. Born to die: disease and New World conquest, 1492-1650. Cambridge: Cambridge University Press, 1998.

CORBIN, Alain. Saberes e odores: o olfato e o imaginário social nos séculos dezoito e dezenove. São Paulo: Cia das Letras, 1987.

CORMIER, Loretta. Kinship with monkeys: the Guajá foragers of Eastern Amazonia. New York: Columbia University Press, 2003.

. Um aroma no ar: a ecologia histórica das plantas anti-fantasma entre os Guajá da Amazônia. Mana, Rio de Janeiro, v. 11, n. 1, p. 129-154, 2006.

CROCKER, Jon Christopher. Vital souls: bororo cosmology, natural symbolism and shamanism. Tucson: University of Arizona Press, 1985.

CROSBY, Alfred. The Columbian exchange: biological and cultural consequences of 1492. Westport: Greenwood Press, 1972.

CUNHA, Manuela Carneiro; ALMEIDA, Mauro W.Barbosa (Org.). Enciclopédia da floresta: o Alto Juruá: práticas e conhecimentos das populações. São Paulo: Cia. das Letras, 2002.

DAMATTA, Roberto; SOÁREZ, Elena. Águias, burros e borboletas: um estudo antropológico do jogo do bicho. Rio de Janeiro: Rocco, 1999.

DESCOLA, Philippe. Constructing natures: symbolic ecology and social practice. In: DESCOLA, Philippe; PÁLSSON, Gísli (Org.). Nature and society: anthropological perspectives. London: Routledge, 1996.

- Ecologia e cosmologia. In: DIEGUES, Antônio Carlos (Org.). Etnoconservação: novos rumos para a proteção da natureza nos trópicos. São Paulo: Annablume/NUPAUB/Hucitec, 2000.

. Estrutura ou sentimento: a relação com o animal na Amazônia. Mana, Rio de Janeiro, v. 4, n. 1, p. 23-45, 1998.

ERIKSON, Philippe. Reflexos de si, ecos de outrem: efeitos do contato sobre a autorepresentação Matis. In: ALBERT, Bruce; RAMOS, Alcida (Org.). Pacificando o branco: cosmologias do contato no norte-amazônico. São Paulo: Imprensa Oficial/Edunesp/IRD, 2002. 
. The social significance of pet-keeping among the Amazonian Indians. In: PODBERSCEK, Anthony; PAUL, Elizabeth; SERPELL, James (Ed.). Companion animals and us: exploring the relationships between people and pets. Cambridge: Cambridge University Press, 2000.

ESCOBAR, Ana Lúcia et al. Causas de internação hospitalar indígena em Rondônia: o distrito especial indígena Porto Velho (1998-2001). In: COIMBRA JUNIOR, Carlos E. A.; SANTOS, Ricardo Ventura; ESCOBAR, Ana Lucia (Org.). Epidemiologia e saúde dos povos indígenas no Brasil. Rio de Janeiro: Fiocruz/ABRASCO, 2003.

FAGAN, Brian. O aquecimento global: a influência do clima no apogeu e declínio das civilizações. São Paulo: Larousse, 2009.

FARAGE, Nádia. As flores da fala: práticas retóricas entre os Wapishana. 1997. Tese (Doutorado em Letras) - Universidade de São Paulo, São Paulo, 1997.

FAUSTO, Carlos. Inimigos fiéis: história, guerra e xamanismo na Amazônia. São Paulo: Edusp, 2001.

FEARNSIDE, Philip. A ocupação bumana de Rondônia: impactos, limites e planejamento. Brasília: Programa Polonoroeste/SCT-PR/CNPq, 1989. (Relatório de Pesquisa, n. 5).

FÓLLER, Maj-lis. Intermedicalidade: a zona de contato criada por povos indígenas e profissionais de saúde. In: LANGDON, Esther. J.; GARNELO, Luiza (Org.). Saúde dos povos indígenas: reflexões sobre antropologia participativa. Rio de Janeiro: Contra Capa/ABA, 2004.

GIANNINI, Isabelle. A ave resgatada: "a impossibilidade da leveza do ser". 1991. Dissertação (Mestrado) - Universidade de São Paulo, São Paulo, 1991.

GOW, Peter. Of mixed blood: kinship and history in Peruvian Amazonia. Oxford: Clarendon Press, 1991.

. 0 parentesco como consciência humana: o caso dos Piro. Mana, Rio de Janeiro, v. 3, n. 2, p. 39-65, 1997.

HEMMING, John. Amazon frontier: the defeat of the brazilian indians. London: MacMillan, 1987.

HUG0, Victor. Desbravadores. Porto Velho: Edição do autor/Beron, 1991.

IRAQUE: 162.000 pessoas mortas desde a invasão americana. Disponível em: $<$ http://ne10.uol.com.br/canal/cotidiano/internacional/noticia/2012/01/02/ 
iraque-162000-pessoas-mortas-desde-a-invasa0-americana-318716.php>. Acesso em: 5 jun. 2012.

KEIFENHEIM, Bárbara. Suicide à la Kashinawa. Le désir de l'au-delà ou la séduction olfactive et auditive par les esprits des morts. Journal de la Société des Américanistes, n. 88, p. 91-110, 2002.

KELLNER, Douglas. The persian gulf TV war. Boulder: Westview Press, 1992.

KENSINGER, Kenneth. How real people ought to live: the Cashinahua of eastern Peru. Prospect Heigths: Waveland Press, 1995.

KIETZMAN, Dale. Indians and culture areas of twentieth century Brazil. In: HOPPER, Janice. (Ed.). Indians of Brazil in the twentieth century. Washington: Institute for Cross-Cultural Research, 1967. p. 3-51.

KIRSCH, Stuart. Reverse anthropology: indigenous analysis of social and environmental relations in New Guinea. Stanford: Stanford University Press, 2006.

KUNITZ, Stephen. Disease and the destruction of indigenous populations. In: INGOLD, Tim (Org.). Companion encyclopedia of anthropology: humanity, culture and social life. London: Routledge, 1994.

LIMA, Edilene Coffaci. Com os olhos da serpente: homens, animais e espíritos nas concepções Katukina sobre a natureza. 2000. Tese (Doutorado em Antropologia Social) - Universidade de São Paulo, São Paulo, 2000.

LIMA, Tânia Stolze. A vida social entre os Yudjá (índios Juruna). 1986. Dissertação (Mestrado) - Universidade Federal do Rio de Janeiro, Rio de Janeiro, 1986.

LIMA, Tânia Stolze. Um peixe olhou para mim: o povo Yudjá e a perspectiva. São Paulo: Edunesp/ISA, 2006.

MEIRELES, Denise Maldi. Populações indígenas e a ocupação bistórica de Rondônia. 1984. Dissertação (Mestrado) - Universidade Federal do Mato Grosso, Cuiabá, 1984.

MONTAGNER, Delvair. A morada das almas: representações das doenças e das terapêuticas entre os Marúbo. Belém: MPEG, 1996.

MOSER, Lílian. Os Karitiana e a colonização recente em Rondônia. 1993. Trabalho de Conclusão de Curso (Graduação em História) - UNIR, Porto Velho, 1993. 
NOVAES, Marlene Rodrigues de. A caminho da farmácia: pluralismo médico entre os Wari' de Rondônia. 1996. Dissertação (Mestrado em Antropologia Social) -Universidade Estadual de Campinas, Campinas.

OVERING, Joanna. There is no end of evil: the guilty innocents and their fallible god. In: PARKIN, David (Org.). The anthropology of evil. Oxford: Basil Blackwell, 1985a.

. Today is hall call him 'mummy'. In: OVERING, Joanna (Org.). Reason and morality. London: Tavistock, 1985b.

PARAGUASSU-CHAVES, Carlos. Geografia médica ou da saúde: espaço e doença na Amazônia Ocidental. Porto Velho: Edufro, 2001.

PERES, Sidnei. Antropologia, ecologia e sociedades indígenas na Amazônia: a trajetória de um discurso. Temáticas, Campinas, v. 7, n. 13-14, p. 183-218, 1999.

PINHEIR0, Manoel T. da Costa. Explorações do Rio Jacy-Paraná. Rio de Janeiro: Papelaria Macedo, 1910. (Commissão de Linhas Telegraphicas Estrategicas de Matto Grosso ao Amazonas, n. 5).

POSEY, Darrell; ELISABETSKY, Elaine. Conceito de animais e seus espíritos em relação a doenças e curas entre os índios Kayapó da aldeia Gorotire, Pará. Boletim do Museu Paraense Emilio Goeldi, Belém, v. 7, n. 1, p. 21-36, 1991.

REICHEL-DOLMATOFF, Gerardo. Cosmology as ecological analysis: a view from the rainforest. Man, London, v. 11, n. 3, p. 307-318, 1976.

. Desana: le symbolisme universel des indiens Tukano du Vaupés. Paris: Gallimard, 1968.

. Tapir avoidance in the Colombian Northwest Amazon. In: URTON, Gary. (Ed.). Animal myths and metaphors in South America. Salt Lake City: University of Utah Press, 1985.

RIBEIR0, Berta. Amazônia urgente: cinco séculos de história e ecologia. Belo Horizonte: Itatiaia, 1990.

RONDON, Cândido M. da Silva. Commissão de linhas telegraphicas estrategicas de Matto Grosso ao Amazonas. Rio de Janeiro: Papelaria Luiz Macedo, 1907. Relatório apresentado à Directoria Geral dos Trabalhadores e à Divisão de Engenharia (G.S.) do Departamento de Guerra. Vol. 1: Estudos e Reconhecimento. 
SAHLINS, Marshall. Historical metaphors and mythical realities: structure in the early history of the Sandwich Islands Kingdon. Canadá: The University of Michigan Press, 1981.

SEEGER, Anthony. Nature and society in central Brazil: the Suya indians of Mato Grosso. Cambridge: Harvard University Press, 1981.

SHEPARD JUNIOR, Glenn H. A sensory ecology of medicinal plant therapy in two Amazonian societies. American Anthropologist, Washington, v. 106, n. 2, p. 252$266,2004$.

SILVA, Christiano Barros Marinho. "Vai-te para onde não canta galo, nem boi urra...": diagnóstico, tratamento e cura entre os Kariri-Xocó. Maceió: Edufal, 2004. (Coleção Índios do Nordeste: temas e problemas, v. 5).

STRATHERN, Marilyn. Property, substance and effect: anthropological essays on persons and things. London: Athlone, 1999.

SZTUTMAN, Renato. Sobre a ação xamânica. In: GALLOIS, Dominique (Org.). Redes de relações nas Guianas. São Paulo: Associação Editorial Humanitas/ Fapesp, 2005.

TAUSSIG, Michael. Xamanismo, colonialismo e o homem selvagem: um estudo sobre o terror e a cura. São Paulo: Paz \& Terra, 1993.

TURNER, Terence. Baaridjumoko em Altamira. Aconteceu Especial, São Paulo, v. 18, p. 337-338, 1991.

UJVARI, Stefan. Meio ambiente e epidemias. São Paulo: SENAC, 2004.

VELDEN, Felipe Vander. Banhos de sangue: relatos Karitiána de guerras, canibalismo e troféus humanos. In: CABRAL, Ana Suelly Arruda et al. Linguas e culturas. Campinas: Editora Curt Nimuendajú, 2011. p. 27-58.

. Circuitos de sangue: corpo, pessoa e sociabilidade entre os Karitiana. Habitus, Goiânia, v. 5, n. 2, p. 275-300, jul./dez. 2007.

. De volta para o passado: territorialização e 'contraterritorialização' na história karitiana. Sociedade e Cultura, Goiânia, v. 13, n. 1, p. 55-65, jan./jun. 2010b.

. Inquietas companhias: sobre os animais de criação entre os Karitiana. 2010a. Tese (Doutorado em Antropologia Social) - Unicamp, Campinas, 2010. 
VELDEN, Felipe Vander. 0 gosto dos outros: o sal e a transformação dos corpos entre os Karitiana no sudoeste da Amazônia. Temáticas, Campinas, v. 31, p. 11-41, 2008.

Por onde o sangue circula: os Karitiana e a intervenção biomédica. 2004. Dissertação (Mestrado em Antropologia Social) - Universidade Estadual de Campinas, Campinas, 2004.

VERANI, Cibele. Representações tradicionais da doença entre os Kuikuro (Alto Xingu). In: BUCHILLET, Dominique (Org.). Medicinas tradicionais e medicina ocidental na Amazônia. Belém: MPEG/CNPq/PR/Cejup/UEP, 1991.

WAGNER, Roy. A invenção da cultura. São Paulo: Cosac Naify, 2010.

WAWZYNIAK, João Valentin. Curupira "engerado" em Ibama: apreensão de um órgão público federal em termos cosmológicos”. Teoria e Pesquisa, São Carlos, v. 44-45, p. 5-18, 2004.

. "Engerar": uma categoria cosmológica sobre pessoa, saúde e corpo. Ilha, Florianópolis, v. 5, n. 2, p. 33-55, 2003.

WELZER, Harald. Guerras climáticas: por que mataremos e seremos mortos no século 21. São Paulo: Geração Editorial, 2010.

WIIK, Flávio. Contato, epidemias e corpo como agentes de transformação: um estudo sobre a AIDS entre os índios Xokléng de Santa Catarina, Brasil. Cadernos de Saúde Pública, Rio de Janeiro, v. 17, n. 2, p. 397-406, 2001.

WRIGHT, Robin. Ialanawinai: o branco na história e mito Baniwa. In: ALBERT, Bruce; RAMOS, Alcida (Org.). Pacificando o branco: cosmologias do contato no norte-amazônico. São Paulo: Imprensa Oficial/Edunesp/IRD, 2002. 